\title{
Culture, Nature, and the Valuation of Ecosystem Services in Northern Namibia
}

\author{
Michael Schnegg $^{1}$, Robin Rieprich $^{1}$ and Michael Pröpper ${ }^{1}$
}

\begin{abstract}
Defining culture as shared knowledge, values, and practices, we introduce an anthropological concept of culture to the ecosystem-service debate. In doing so, we shift the focus from an analysis of culture as a residual category including recreational and aesthetic experiences to an analysis of processes that underlie the valuation of nature in general. The empirical analysis draws on ethnographic fieldwork conducted along the Okavango River in northern Namibia to demonstrate which landscape units local populations value for which service(s). Results show that subjects perceive many places as providing multiple services and that most of their valuations of ecosystem services are culturally shared. We attribute this finding to common experiences and modes of activities within the cultural groups, and to the public nature of the valuation process.
\end{abstract}

Key Words: concept of culture; ecosystem services; ethnography; landscapes, Namibia; valuation

\section{INTRODUCTION}

The scientific concept of "ecosystem services" is increasingly used to create a value-based foundation for natural resource management (Costanza et al. 1997, De Groot et al. 2002, Millennium Ecosystem Assessment 2005, Daily et al. 2009, Bateman et al. 2013). The Millennium Ecosystem Assessment (MA) classifies the four broad categories of (1) provisioning, (2) regulating, (3) supporting, and (4) cultural ecosystem services (Millennium Ecosystem Assessment 2005, UK National Ecosystem Assessment 2011, Haines-Young and Potschin 2013). Provisioning services are the material contributions ecosystems offer in satisfying essential human needs, such as nutrition, shelter, and safety (Daniel et al. 2012). Regulating services include the multiple ecological processes necessary to balance the world's lifesupport system, such as climate regulation and flood regulation (De Groot et al. 2002, Millennium Ecosystem Assessment 2005). Supporting services, e.g., nutrient cycling and soil formation, contribute to sustaining provisioning and regulating services (Millennium Ecosystem Assessment 2005). Finally, and to "complement or counterbalance considerations of utilitarian value" (Millennium Ecosystem Assessment 2003:127), the MA defines cultural ecosystem services (CES) as the "nonmaterial benefits people obtain from ecosystems through spiritual enrichment, cognitive development, reflection, recreation, and aesthetic experiences" (Millennium Ecosystem Assessment 2005:40). Whereas most ecosystem services deal with "material" processes such as the provision of goods including food, fiber, or water, and the biochemical processes behind them, CES do not. Many scholars have noticed that "nonmaterial" services account for a great part of why humans value nature and, therefore, CES must be included in considerations of management (Millennium Ecosystem Assessment 2003, Chan et al. 2012a, Daniel et al. 2012, Haines-Young and Potschin 2013).

The overall aim of the ecosystem-service approach is to account for all of the values nature provides and to include these in landuse decisions (Shukdev 2009, The Economics of Ecosystems and Biodiversity 2010). To achieve this goal, each of these services is defined and measured, e.g., the amount of food provided or $\mathrm{CO}_{2}$ stored. A value is attached to these quantities, generally by estimating a market value in terms of current prices or the prices people claim they are willing to pay for a service (Costanza et al. 1997, 2011, Kubiszewski et al. 2013). By summing these value estimates for all ecological services, one arrives at an overall monetary value of a landscape at current market conditions or for the individual(s) concerned. For example, Costanza et al. (2006) estimated that in 2004, New Jersey's forests provided a dollar value of US\$2.2 billion/yr in ecosystem services, while the state's beaches accounted for US\$330 million/yr (Costanza et al. 2006). These estimates allow stakeholders involved in environmental decision making to assess how much the value of a particular ecological system might change with the implementation of different land-management strategies; for example, if forests were to be cleared for agriculture.

Although this approach to valuing ecosystem services has gained increasing acceptance over the last decade, there remain unresolved questions about its validity (Wallace 2007, Costanza 2008, Fisher and Turner 2008). Of primary importance for our research is the problematic consideration of culture as a category of value that is completely separate from the material values of other ecosystem services (Chan et al. 2012a, Chan et al. 2012b, Daniel et al. 2012, Satterfield et al. 2013, Satz et al. 2013). Typically, the challenges associated with valuing cultural ecosystem services involve finding an adequate methodology for defining, measuring, and assigning a market or subjective value to spiritual, cognitive, recreational, or aesthetic qualities. In recent years, scholars have developed two main approaches to address this challenge: CES are either measured in monetary terms or through qualitative descriptions and assessments. The 2011 UK National Ecosystem Assessment (UKNEA) provides an example of the former approach, using economic proxies such as willingness to pay to experience the values of the environmental setting. Examples of payment include the travel expenses people are willing to incur to get to a recreational area, or variations in housing prices according to the environmental setting (Church et al. 2011:643ff.). The second approach partly leaves the monetary scale behind, and focuses on the psychological and discursive construction of values. For example, Wilson and Howarth (2002) stress the need to think beyond the merely utilitarian individual 
and push to analyze discourses that emerge in discussions and public debates (Wilson and Howarth 2002). Kumar and Kumar (2007:817) criticize the traditional economic approach and urge the use of qualitative research methodologies informed by social constructionism, ecopsychology, and psychoanalytic psychology. At the same time, these authors admit that their recommendations need further elaboration and they provide little empirical evidence of their use or potential advantages (Wilson and Howarth 2002:437, Kumar and Kumar 2007).

However, in our view, the fundamental problem is not measurement but the strict separation of "culture" and "nature," creating a contrast which, some have argued, is itself a western cultural construct informing lay and scientific thinking about ecosystem services (Latour 1999, Descola 2005). The MA categorization draws unreflectively on a popular, as opposed to scholarly, definition of culture, which is particularly characteristic of the experienceable human-nature interactions of the middle and upper classes. This definition specifies the cultural ecosystem services as those services that provide nontangible spiritual, cognitive, or aesthetic enjoyment and enrichment, in contrast to those that productively satisfy material resource and wastetreatment needs. Cultural ecosystem services are seen as a residual category of enjoyable aspects of nature, much as the fine arts may be enjoyed as a form of "cultural enrichment" (Millennium Ecosystem Assessment 2005:40).

This problem is not peculiar to the ecosystem-service debate. Despite regular attempts to emphasize the inextricable link between culture and nature (Posey 1999) the literature has long treated them as rather separate domains. Early work on biocultural diversity treated biology and culture as separate spheres (Gadgil 1987) and suggested indicators to measure and correlate them (Moore et al. 2002). Language, ethnicity, religion, and other domains served as proxies for culture and determined its heterogeneity within spatial entities (Skutnabb-Kangas et al. 2003, Maffi 2005:610). Using the same logic, the diversity of bird/ mammal and plant species was used to determine biological diversity. In the end, those two measures were spatially correlated to determine whether cultural and biological diversity go hand in hand (Moore et al. 2002).

At the center of subsequent debates was the argument that the "cultural" in "biocultural" has some sort of protective function, as cultural was often used to describe indigenous and local people's successful attempts to protect species and habitats (Cocks 2006:187). Thus, "cultural" was used to indicate that indigenous people would value natural resources largely because of immaterial properties such as spiritual importance (Groenfeldt 2003) or as part of their own group identity (Posey 1999, Laird 1999) or by ascribing symbolic significance to surrounding landscapes (Infield 2001). Cocks has pointed out clearly that this conception of cultural values is too narrow. She criticizes Posey (1999), Laird (1999), and others for overemphasizing protective properties in their portrayal of the cultural value of nature, such as hosting spirits, providing dwelling places for ancestors, and being sites for ritual ceremonies (Cocks 2006:188-193). Broadening the definition of culture to encompass something that unites not only indigenous, traditional, and local people but also people in transformed and diversified livelihood settings and lifestyles (Cocks and Wiersum 2003), Cocks argues that the harvest and use of natural resources in changing and mundane contexts is also driven by cultural motives and often also fulfils a cultural value (Cocks 2006:190). That is, such actions serve livelihood needs and simultaneously contribute to the constitution of identity and belonging (Cocks 2006:191-193). More recently, and very much in line with our findings, Cocks et al. (2013) have demonstrated that the experience of these values does not take place in isolation but is often intertwined with activities such as collecting fuelwood (2013:5).

We acknowledge this approach as a major step forward for the ecosystem-service debate, as it provides a lens for understanding the close relationship that people from different cultures have with nature. However, the literature still provides few tools for analyzing the connection in-depth. Our motivation here is to offer a methodology that allows exploring this entanglement in more detail. Our approach gives increased recognition to the fact that people share cultural meanings, which they attach to nature. Our methodology aims to shift the focus from an analysis of cultural, as opposed to natural, ecosystem services to an analysis of the cultural valuation of all ecosystem services. For example, whether most people in a group eat insect larvae or beef, which are provisioning services, is not only a natural but also a cultural choice. To address these concerns, we deploy a concept of culture from cognitive and ecological anthropology that is well developed in the literature (D'Andrade 1995, Medin et al. 2006), to show how it is possible to empirically determine people's understandings of material, social, and aesthetic aspects of their natural environment, and how those conceptions are shared.

\section{AN ANTHROPOLOGICAL APPROACH TO CULTURE}

Since the foundation of the discipline, social and cultural anthropologists have actively debated what culture is. In the late $19^{\text {th }}$ century, Tylor (1871) offered an early definition, differing significantly from the lay conception which equated culture with the fine arts. He defined culture as "that complex whole which includes knowledge, belief, art, morals, law, custom, and any other capabilities and habits acquired by man as a member of society" (Tylor 1871:1). Although this perspective on culture encompasses aesthetics, recreational and educational activities, and the spirituality of places, it does not limit culture exclusively to nonmaterial categories. Culture becomes a complex whole that includes norms and values governing nature, and social organization, including family and kinship, religious life, politics, and economy as well as the ways activities in these domains are practiced (Kuper 1999). Although his definition and subsequent approaches (e.g., Radcliffe-Brown 1935, Murdock 1949, Geertz 1973) overcame the narrow focus on the aesthetic, they still suffered from a major drawback - they conceptualized culture and cultures as rather homogeneous entities. In that sense, a society, i.e., a group of people, had one culture.

Since the 1980s, anthropologists have questioned this position and have argued that cultural homogeneity and boundedness are largely a construction of anthropologists themselves, who formed groups through describing them (Marcus and Fischer 1986). In the same vein, the critique pointed out that societies are much more heterogeneous and dynamic than earlier conceptions had allowed for (Ingold 2002:330). To overcome these concerns, some have advocated abandoning the concept altogether and sticking to individual articulations of social reality (Abu-Lughod 1991). 
Although this debate raised sound concerns, many questioned the validity of its premises. Even though voices are more diverse and distributed than initially thought, we find shared understanding and coherence in many social fields (D'Andrade 1995).

An alternative and very promising attempt to conceptualize culture, which is especially well suited to understanding the processes we focus on, is being developed at the intersection of cognitive and ecological anthropology. This view acknowledges heterogeneity and the dynamics of social systems, while recognizing that certain perceptions and practices are shared. Medin et al. (2006) argue that culture should be understood as "causally distributed patterns of ideas, their public expressions, and the resultant practices and behaviors in a given ecological context." They continue: "This distributive view of culture is a significant departure from the shared norms and rules perspective in that variable distributions of ideas within a culture become an important object of study instead of nuisance" (Medin et al. 2006:28). Thus, this approach defines culture as shared ideas and practices, without presupposing that a society has a single culture, but at the same time it does not abandon the notion of culture altogether. Instead, the "distributional view" turns the question of whether and where a shared cultural model exists into an empirical concern.

The cultural consensus model (CCM) has been developed to apply this concept of culture; it consists of a set of techniques to statistically demonstrate the degree of cultural consensus or lack thereof (Medin et al. 2006:29). This model is based on the assumption that those who know more tend to agree with one another; that is, cultural experts are more likely to agree on an issue than novices or randomly selected informants. The CCM allows us to: (1) identify the cultural model of a given domain, (2) quantify the degree to which knowledge is shared, and (3) evaluate the cultural competence of individual informants (Weller 2007:344ff.)

It is hard to overestimate the importance of the CCM for our approach. Conceiving of culture as shared knowledge, practices, and beliefs provides a framework for overcoming the divide between nature and culture. The approach acknowledges that ecosystem services, whether material or nonmaterial, become services through sociocultural constructions. To operationalize this conception of culture for our analysis, we define the valuation of ecosystem services as the understanding of an individual with regard to which landscape units provide which material and nonmaterial services. If these individual valuations are shared among a group of people, e.g., in a village, this justifies referring to those valuations as one cultural model, which can then be interpreted as the cultural valuation of ecosystem services. However, if the individuals' views are highly idiosyncratic, the notion of a single, culturally shared valuation is not justified. In sum, where others refer to culture vs. nature, we speak of material and nonmaterial services, and we assume that both are culturally constructed and potentially shared. This approach translates into two research questions that we have applied in a case study in northern Namibia. (1) Do land users share a cultural model with regard to which landscape units provide which services, and how strong is their consensus? (2) How do material and nonmaterial services relate in this model, and how can the relations be explained by social practices? Before we answer both questions, we introduce the research setting and the methods used.

\section{METHODS}

Over the last three years, we have conducted ethnographic fieldwork in the Okavango basin as part of the international and interdisciplinary research project, The Future Okavango (TFO), which aims at understanding the ways in which ecosystem services are provided by nature and used and valued by local inhabitants. During our fieldwork in Namibia, we applied a mixed-methods research design, including participatory mappings of landscape values, to explore which services are assigned to which landscape units (Lynam et al. 2007, Raymond et al. 2009, Fagerholm et al. 2012). The specific fieldwork reported on here was carried out in Mahahe, north-east Namibia, between September-December 2011 by one of the authors (R. Rieprich).

Mahahe is a rural community of about 50 households within the political-administrative region of Kavango, situated $50 \mathrm{~km}$ east of the town of Rundu. As in many rural areas of southern Africa, people acknowledge numerous material and nonmaterial ecosystem services that play a crucial role in local livelihoods and in the well-being of households (Mendelsohn and el Obeid 2004, Pröpper 2009). Local inhabitants increasingly desire money, which is generated through casual work, state pensions, the selling of natural resources, or through family members working outside of the village. The money is used to buy groceries, beer, and drugstore products from small local shops and to pay for school fees, medication, and transportation.

The data are based on three main components: (1) participatory mappings, (2) ethnographic participant observations, and (3) semistructured interviews. Whereas the participatory mappings provide the backbone of the analysis presented, the information derived from the other methods adds depth. Participatory mappings of landscape values have been developed to visualize locally perceived ecosystem services spatially (Raymond et al. 2009, Brown et al. 2012, Fagerholm et al. 2012, Plieninger et al. 2013). In contrast to an exact ecological measurement of services provided by a landscape unit, the participatory mapping elicits the views of local actors who value and utilize services in daily routines. Focusing on individuals and their subjective perspectives on nature allows ecosystem services as distributed in landscape units to be viewed as if through the actors' eyes.

For the landscape mapping, we selected 16 informants in a nonprobability sampling procedure, striving for an ethnographic sample that is heterogeneous according to various social categories including gender, age, and ethnicity (Werner and Bernard 1994). Approximately $30 \%$ of the 50 households of Mahahe were represented in the sample by a household member. The sample consisted of eight female and eight male permanent inhabitants of Mahahe, the youngest being 18 yrs of age and the oldest 92. The median was $45 \mathrm{yrs}$ and the first and third quartiles were 24.5 and 56.75 yrs respectively. All major ethnic groups of the research site, comprising Nyemba, Kwangali, Sambyu, Gciriku, and Mbukushu, were represented. All informants considered themselves Christian; however, coexisting with Christian beliefs, traditional concepts of religion also play an important role throughout the Kavango (Pröpper 2009). Except for two elderly persons, all informants were involved in common economic activities including agriculture, fishing, and the gathering of fruits, fuelwood, and plants. The sample excluded migrant workers, who stay in Mahahe only occasionally, given their lack of availability for interviews. 
During the fieldwork, the researcher lived in Mahahe so that his everyday activities such as fetching water, shopping, and walks through the village would put him in contact with a larger number of the inhabitants, and also offer the possibility for informal conversations and observations. The researcher established close social relationships with about 10 informants who were all part of the sample of the mapping exercise described above. He was invited to accompany them for everyday work routines such as plowing, fishing, and fetching grass, as well as for social activities including family dinners and visiting relatives. This group also covered different age groups and genders; however, it was slightly biased toward young men, as this group proved to be particularly open and approachable to the researcher, who shared their demographic.

Beyond the participant observation, which went on throughout the researcher's presence in the field, the fieldwork can roughly be divided into three phases. (1) Initially, 29 informants, including the group of 16 described above, along with 13 extra informants, participated in a first round of personal interviews in SeptemberOctober 2011. These semistructured interviews served to provide an overview of local structuring of space and of everyday ways of interacting with landscapes; e.g., fishing and farming. Moreover, spiritual and symbolic meanings, and medical uses of certain plants, were sought. The interviews were accompanied by transect walks with some of the informants in the forests, floodplains, and agricultural areas. (2) As a second step, the participatory mapping sessions took place in November 2011. (3) The third phase was another round of semistructured interviews in December 2011, which served as a follow-up to the mappings. Twenty-three of the initial 29 informants (six being unavailable for various reasons) were interviewed to validate and deepen the data of the interviews, particularly through questioning about the meanings of certain places and about activities that were salient in the mapping. All personal names given are pseudonyms to ensure the anonymity of the informants.

The observations, transect walks, and semistructured interviews conducted during the first step of the research were analyzed with this question in mind: "In what ways can landscapes contribute to a good life?" Based on the results, a preliminary categorization of landscape services was elicited, which was informed by current literature (Brown et al. 2002, Denzin 2005, Costanza et al. 2007) and was discussed with, and validated by, local informants. Thirteen categories were finally delineated. In Table 1, we show the definitions of material and nonmaterial services given to the informants in the interviews; the definitions were deliberately formulated broadly to avoid predetermining the responses.

For the mapping sessions, the 16 informants were invited to identify the places where they located the particular services by placing stickers on a satellite image (size: A0; $841 \times 1189 \mathrm{~mm}$ ) showing an area of $35 \mathrm{~km}^{2}$ with Mahahe at the center; the section is equal to the map extract in Fig. 1. Without exception, the respondents navigated the map with confidence, and most of them enjoyed the novel perspective on their village. The 13 services were mapped consecutively; each category was represented by a round sticker that was $10 \mathrm{~mm}$ in diameter and of a specific color. Interview questions were formulated by a research assistant in the local languages RuKwangali and RuSambyu, and the interviews lasted 30-90 minutes.
Table 1. Categories of services and definitions used for participatory mappings.

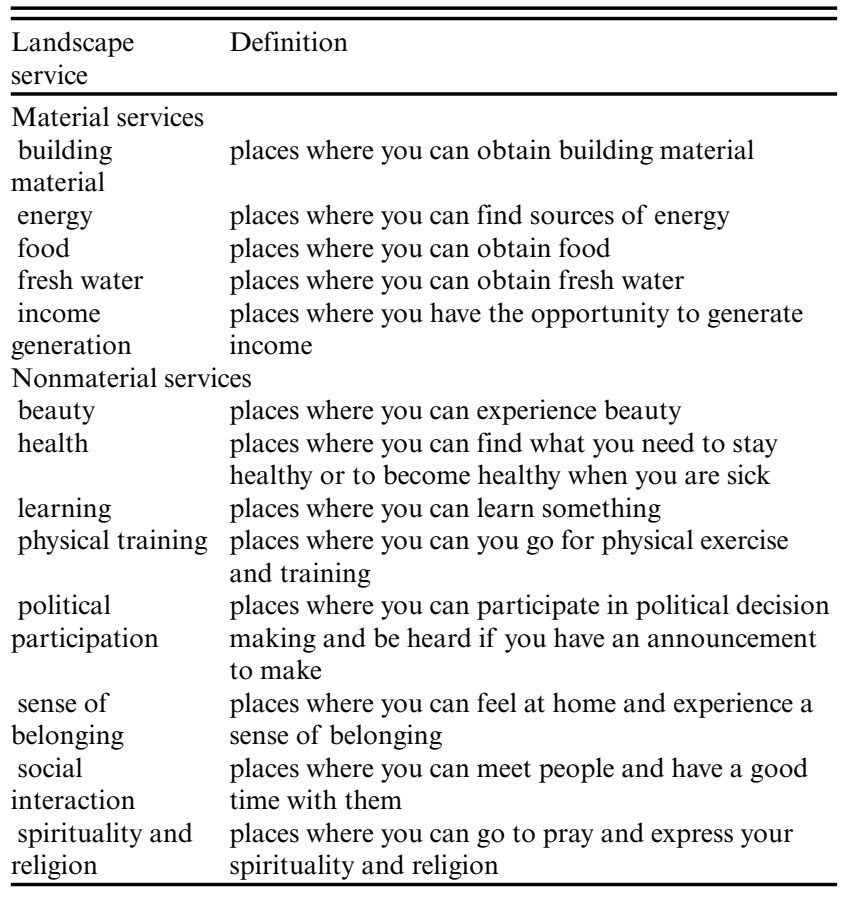

At the end of the interviews, we recorded the spatial positions of each informant's stickers by photographing the map. The positions of the stickers, as well as qualitative attribute data, were digitized for further analysis using ArcGIS 10.1. The attribute data of the points included sociodemographic data for informants, and the categories of services (see Table 1). Maps showing the intensity of set points in space were then generated using ArcGIS 10.1 and its kernel density tool (Silverman 1986). The tool allows for the identification of areas on the map in which the density of points is high, or above a certain threshold.

From this data, we generated a matrix for each informant containing information on whether one of the 13 services was seen in each of the 10 landscape units. Thus, each matrix had 13 rows and 10 columns. We then combined all 16 matrices to give a single aggregate matrix. This was submitted to consensus analysis to test for the agreement that would indicate the shared understanding of the informants. Cultural consensus analysis is a well-established methodological tool in cognitive anthropology, and has been widely applied in ethnobotanical research and medical anthropology (Romney et al. 1987, Weller et al. 2002). To find the shared, and hence, cultural answer, the model first calculated the level of agreement among all informants, which is adjusted for the probability of guessing. This agreement matrix was submitted to a factor analysis to test whether the informants shared a single underlying model. The agreement could be evaluated statistically using the ratio of the first to the second factor from a factor analysis used to decompose the overall agreement matrix. If the first factor was three times larger than the second, and if all informants had positive competence values, the cultural consensus would be high. Factor loading on the first 
Fig. 1. Landscape units of Mahahe (scale 1:60,000).

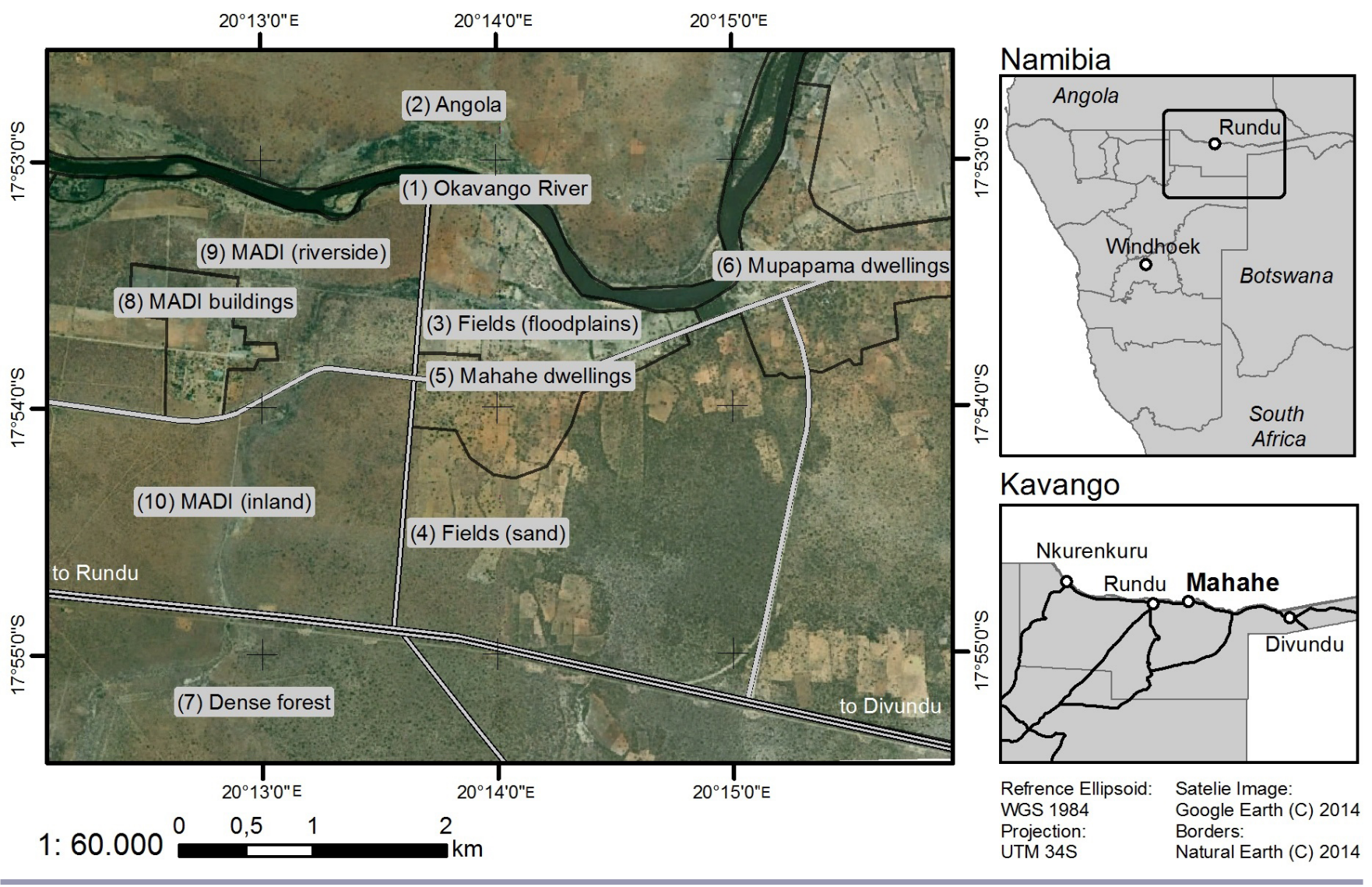

factor reflects the cultural competence of each informant. Theoretically, those factor loadings have an undefined range. However, "because the competence scores are interpreted as the proportion of answers that each person knows (and does not guess), the scores must range between 0 and 1, inclusive. Values $<0$ or $>1$ are undefined (Weller 2007:346). The closer the score approaches 1 , the higher the competence of the informant. In a final step of the analysis, these competence scores were used to weight individual answers and to determine the overall, and thus shared, cultural model (Romney at al. 1986, Batchdelder and Romney 1988, Weller 2007:344ff.).

Our ethnographic approach and semistructured interviews allowed us to contextualize the quantitative and spatial data with regard to social practice. The methods not only helped to identify the most salient ecosystem services, as locally perceived; they were also a means of validating the data from the mappings, i.e., by comparing the spatial data with findings from observations and semistructured interviews. Generally, the informants' marks on the maps seemed to be an adequate representation of their social reality. However, the qualitative methods reveal some weaknesses in the mapping approach. Spirituality and religion in particular did play an important role in everyday actions and decision making, but could not always be located spatially. Whereas some informants marked the churches or their own houses for "practicing spirituality and religion," many informants told us that God could not be ascribed to a certain place, but was omnipresent. Therefore, spiritual services may be underrepresented within the spatial data.

\section{RESULTS}

Based on the insights from transect walks, participant observation, and semistructured interviews, in the first phase of fieldwork we classified the environment surrounding the village of Mahahe into 10 landscape units in accordance with the local structuring of space. These are numbered from 1-10 in Fig. 1.

In the north, the village of Mahahe is adjacent to the Okavango River, which provides fish and fresh water, as well as grasses and reeds used as building material (marked as (1) on Fig. 1). The river marks the political-administrative border with Angola (2), which is easily accessible by canoe, but the use of Angolan resources is prohibited for Namibian residents. Many villagers depend on subsistence farming and cultivate nonirrigated fields on the floodplains (3) as well as inland on sandy soils (4). Between the floodplains and the sandy and sparsely wooded area inland lie the dwellings of Mahahe (5). The local school and a small health post are located two $\mathrm{km}$ east of Mahahe in the neighboring village of Mupapama (6), which is accessible by a gravel road. A few kilometers south of the villages, a tarred road, the Trans-Caprivi highway, leads from Rundu to the Zambian border. The highway divides the areas used for agriculture from dense forests (7), which provide timber and grasses. The Mashare Agricultural Development Institute (MADI) is adjacent to Mahahe in the west. 
The MADI is a governmental organization that aims to provide agricultural training and information to local farmers. The MADI spaces comprise buildings (8); the fenced premises of the institute, used for grazing the institute's livestock, are divided by a gravel road at the riverside (9) and another is found inland (10). Both are covered by forest and bushy vegetation.

Altogether, the 16 respondents mapped 667 points where they perceived a material or nonmaterial service. Thus, on average, each informant marked 41.7 places (sdv. 9.3 points; min. 30 points; max. 64 points). The highest number of points was set by the respondents for the category food (116), followed by income generation (103), and then building material (95). The most frequently marked nonmaterial services were social interaction (51), health (45), and beauty (39). Fig. 2 shows the kernel density surfaces of points set by the informants for three of the 13 services: (1) beauty, (2) social interaction, and (3) food. We chose these categories as examples, as they cover both material and nonmaterial services and were among the most frequently mapped services from those clusters.

If each of our research participants in the mapping task had idiosyncratically arranged, individually unique views on which services could be found in the local environment, we should have found a largely unpatterned distribution of dots in the aggregated raw data and large areas covered on the map after the kernel density analysis. However, this was not the case. The results displayed in Fig. 2 show that all three services overlap considerably in space with common clusters at the Okavango River and the dwellings of Mahahe and Mupapama. This indicates: (1) that a cultural consensus in the participants' valuations of these places was likely, and (2) that material and nonmaterial services were not clearly separated by locality, a finding further substantiated through ethnographic data presented below.

We have introduced cultural consensus analysis to explore the degree to which individuals attribute the same services to the same landscape units. This broadens the scope of the above analysis by taking all landscape units and all services into account. As mentioned, the ratio between the first and the second factor is an indication of the overall consensus. By common interpretation, this ratio should be three or greater (Romney at al. 1986, Batchdelder and Romney 1988, Weller 2007:344ff). In our data, the first factor was more than nine times the second, and all informants had positive competence scores, with an average of 0.573 , and standard deviation of 0.081 . This indicates strongly that the local actors shared a common understanding of where the 13 services were located across the 10 landscape units. To test whether this understanding was even more consensual among subgroups that share certain characteristics, we split the file according to age and gender. However, we did not find significantly higher levels of consensus in these subgroups, indicating a lack of more homogeneous subclusters.

The results of the consensus analysis, illustrated in Table 2, reveal that not only did the local actors agree that the Okavango River was a place to experience beauty and to obtain food, a finding known from Fig. 2, but that there was also consensual appreciation of the same site as a place providing building material and fresh water, as well as opportunities to generate income. However, and in contrast to the observation above which linked the river to social activities, we found no consensus that the river provides space for social interaction. This is consistent with an understanding of culture as a collection of shared meanings that may never be fully homogeneous within a given cultural group. In fact, only informants
Fig. 2. Kernel density clusters for social interaction, beauty, and food services (scale 1:100,000; cell size $50 \mathrm{~m}$, search radius 300 $\mathrm{m})$.
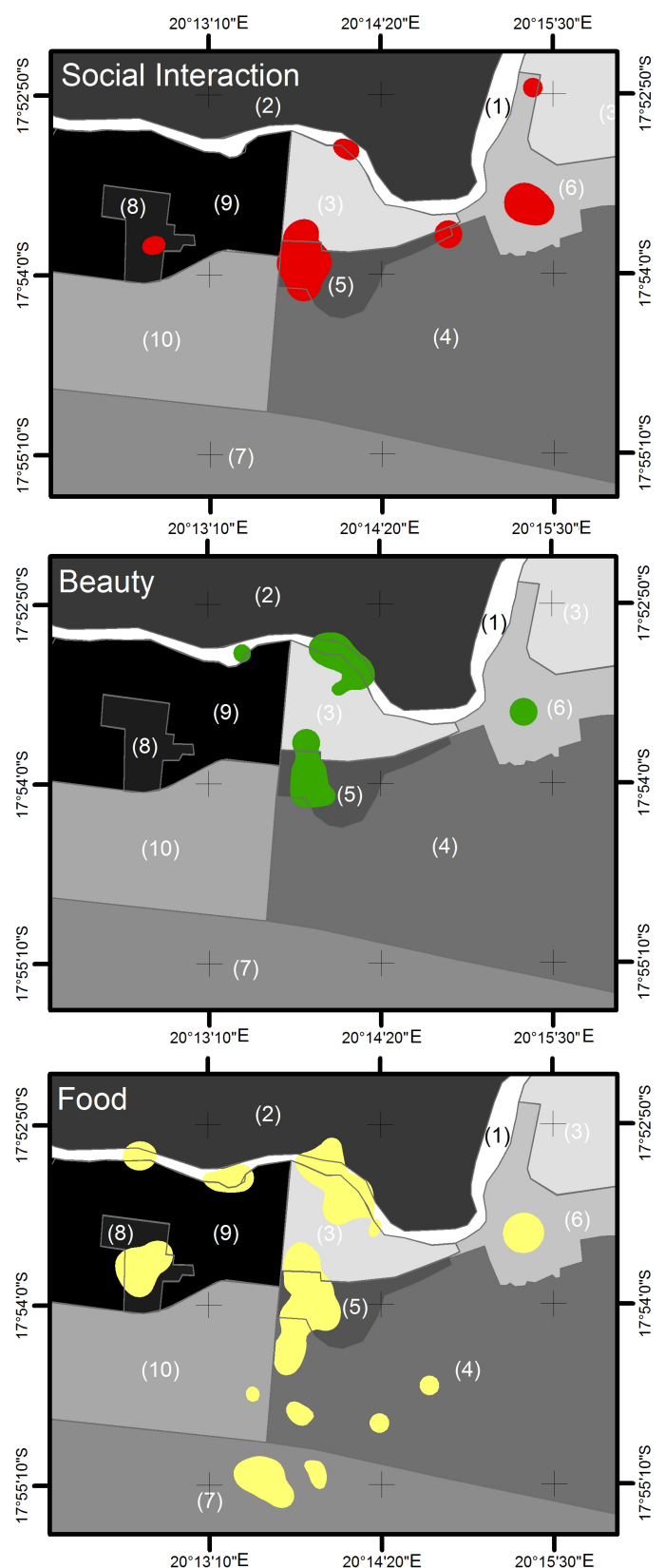

Landscape Unit
(1) Okavango River
(2) Angola
(3) Fields (floodplains)
(4) Fields (sand)
(5) Mahahe dwellings
(6) Mupapama dwellings
(7) Dense forest
(8) MADI buildings
(9) MADI (riverside)
(10) MADI (inland)

Refrence Ellipsoid: WGS 1984 Projection: UTM 34S Kernel Density Cluster $>15$ points $/ \mathrm{km}^{2}$ 
Table 2. Cultural consensus in which landscape unit services can be found.

\begin{tabular}{|c|c|c|c|c|c|c|c|c|c|c|}
\hline & Angola & $\begin{array}{c}\text { fields } \\
\text { (floodplains) }\end{array}$ & $\begin{array}{l}\text { fields } \\
\text { (sand) }\end{array}$ & $\begin{array}{l}\text { MADI } \\
\text { buildings }\end{array}$ & $\begin{array}{l}\text { MADI } \\
\text { (inland) }\end{array}$ & $\begin{array}{c}\text { MADI } \\
\text { (riverside) }\end{array}$ & $\begin{array}{l}\text { Mahahe } \\
\text { dwellings }\end{array}$ & $\begin{array}{l}\text { Mupapama } \\
\text { dwellings }\end{array}$ & $\begin{array}{c}\text { Okavango } \\
\text { River }\end{array}$ & $\begin{array}{l}\text { dense } \\
\text { forest }\end{array}$ \\
\hline \multicolumn{11}{|l|}{ Material services } \\
\hline building material & 0 & 1 & 0 & 0 & 1 & 0 & 0 & 0 & 1 & 1 \\
\hline energy & 0 & 0 & 0 & 1 & 1 & 1 & 0 & 0 & 0 & 0 \\
\hline food & 0 & 1 & 1 & 1 & 0 & 0 & 1 & 1 & 1 & 1 \\
\hline fresh water & 0 & 0 & 0 & 0 & 0 & 0 & 1 & 0 & 1 & 0 \\
\hline income generation & 0 & 1 & 0 & 1 & 0 & 0 & 1 & 0 & 1 & 1 \\
\hline \multicolumn{11}{|l|}{ Nonmaterial services } \\
\hline beauty & 0 & 0 & 0 & 0 & 0 & 0 & 0 & 0 & 1 & 0 \\
\hline health & 0 & 0 & 0 & 0 & 0 & 0 & 1 & 1 & 0 & 0 \\
\hline learning & 0 & 0 & 0 & 0 & 0 & 0 & 1 & 0 & 0 & 0 \\
\hline physical training & 0 & 0 & 0 & 0 & 0 & 0 & 0 & 0 & 0 & 0 \\
\hline political participation & 0 & 0 & 0 & 0 & 0 & 0 & 1 & 0 & 0 & 0 \\
\hline sense of belonging & 0 & 0 & 0 & 0 & 0 & 0 & 0 & 0 & 0 & 0 \\
\hline social interaction & 0 & 0 & 0 & 0 & 0 & 0 & 1 & 1 & 0 & 0 \\
\hline spirituality and religion & 0 & 0 & 0 & 0 & 0 & 0 & 1 & 0 & 0 & 0 \\
\hline
\end{tabular}

younger than 25 yrs mapped the river as a social place and emphasized that their working activities such as fishing or cutting grass often go hand in hand with socializing with friends. The greatest variety of shared valuations was found in the area of the dwellings of Mahahe, where we found a consensus in the occurrence of eight of the 13 categories of services; that is, income generation, learning, food, fresh water, health, political participation, spirituality and religion, and social interaction. Fields, floodplains, and dense forest were particularly valued for providing building material, food, and opportunities for income generation.

Clearly, the people of Mahahe share a cultural model of which landscape units provide which services. We also wished to identify how material and nonmaterial services were intertwined. Figure 1 and Table 2 make it clear that this shared view related both material and nonmaterial services in landscape units, especially in the two dwelling areas and the river. Ethnographic data offer an explanation: both material and nonmaterial services were accessed simultaneously in daily activities and routines. The following detailed descriptive vignettes representing activities that, in the consensual view, relate people to the river and simultaneously provide building material, income, food, fresh water and beauty, makes this clear.

One morning, R. Rieprich and a local research assistant, Sam, accompanied Jeff and Matthias, two young fishermen, on their trip to the Okavango. After a 20-min walk they reached the shores and found two "wato," or canoes, hidden behind a bundle of reeds. They entered the canoes and paddled upstream, looking out for potential threats such as crocodiles or hippopotami. Passing a group of women, they watched them use "muduva," or hand fishtraps, while standing waist-deep in the water. When they reached an island about two $\mathrm{km}$ west of the village, they stopped. Here, the only things they heard were the splashing water, birds, and the reeds blowing in the wind. Jeff commented that it was the freshness of the water, the cool breeze, and the sound of the water he enjoyed so much when fishing, while waiting quietly for the fish to bite. Patiently readjusting the hook, they waited for the first catch. Finally, Jeff felt a bite and brought up a redbreast tilapia. Among many other species, the Okavango is the habitat for the "nkundu," a local term for both the redbreast tilapia (Coptodon rendalli) and banded jewelfish (Emichromis elongates); "hogo," or mountain catfish (Amphiliidae); "nyiru," or tigerfish (Hydrocynus vittatus); "kapanda," or threespot tilapia (Oreochromis andersonii); and "eputu," or squeakers (Mochokidae; Okeyo et al. 2004).

As it became hotter toward midday, the fishermen decided to steer their canoes to a quiet bay. When they arrived at their rest place, Sam and Jeff scuttled into the water, laughing, while Matthias prepared a little fire, around which they gathered in the shade. Some of the smaller fish caught were roasted and shared among all of them. On the way back to the island, Jeff and Matthias joked about enormous fish they claimed to have caught at this very spot, hair's-breadth escapes from crocodiles, and scary creatures living deep down in the river that could hold your canoe and destroy it. The afternoon's catch was successful and soon they counted more than 20 fish in the canoes, some of them of remarkable size. On their way back, after a long day, Sam and Robin asked the fishermen what they enjoyed most about fishing, and Jeff replied: "I enjoy the moment when the fish bites the hook. It feels so thrilling when I am pulling out a big fish from the river" (Interview in Mahahe, 27 October 2011). Walking back to their homes, Sam stayed back to collect a bundle of fuelwood for that night's fire, while Jeff and Matthias hurried to sell their catch.

The fishermen displayed their fish at the local bar next to the main road, as people passing through the village by car were potential buyers. The fish hung under a shady tree. When not even the travelers on the six o'clock bus from Rundu were interested in buying, they walked over to the MADI, where they usually might find customers, although they paid less than in the village. Jeff used the money he earned mainly to support his family, but was also able to buy a cell phone and he tried to save some of his money. Matthias used what he earned to save for buying brandname clothes, and he allowed himself some bottled beer once in a while.

A second common activity, collecting wild fruits, also intertwined a number of different services. Josephine, a 32-yr old woman who 
recently started working in a nearby city, replied when questioned about what she missed most in her new situation:

That would be the fruits that we collect here in the different seasons, because you will see them in town and you will not have money to buy them, so this will make you miss the place that you came from (interview in Mahahe, 13 September 2011).

In Mahahe, wild fruits are highly appreciated as they add diversity to the daily diet. Fruit trees are usually left untouched when fields are cleared for agriculture, and provide both shade and food for people taking breaks from the hard physical work in the fields. How collecting fruits make a place beautiful becomes clear when we consider the following comment by Mary, a 40 yr-old woman. When asked what the most beautiful place in the village was, she replied:

There are these "uguni," "usivi," and "utu" trees that surround us. We go to these places to get fruits [...] and you sit down under a tree to relax with friends while you are enjoying the fruits like "maguni" or "makwewo," so those are the places that are beautiful (interview in Mahahe, 7 November 2011).

The sweet and juicy fruits of uguni/maguni (Strychnos cocculoides), utu (Strychnos pungens), and makwewo (Diospyros chamaethamnus) are usually eaten fresh. However, fruits are not only enjoyed as a material good. Eating them produces a social context in which people interact with one another and the natural environment. Reflecting on the beauty of the place, Mary linked the activity of collecting wild fruits to aesthetic and interpersonal experiences. As we have shown above, it was exactly those interactions that were associated with people's perceptions that nature was beautiful, and not the entity itself. Taken together, both vignettes show how material and nonmaterial services were experienced simultaneously while fishing and collecting wild fruits, and that an aspect of the experience of beauty was constructed partly through this interaction.

\section{DISCUSSION}

Thus far, we have shown that: (1) rural land users share a cultural model of which landscape units provide which services, and (2) the cultural model links material and nonmaterial services in some landscape units. However, relatively few studies have addressed these points to date. Concerning the latter, existing knowledge points in a similar direction. In a recent study, Ramirez-Gomez et al. (2013) analyzed provisioning, cultural, and incomegeneration services within indigenous communities in Suriname. Although the study does not systematically assess overlaps between the categories, the authors indicate that members of the local communities view these services as co-occurring. For example, the seed-finch birds (Oryzoborus angolensis) of the savannah are assigned a cultural significance for their complex songs. At the same time, they are seen as representing opportunities to generate income through tourism and wildlife trade (Ramirez-Gomez et al. 2013:16). Fagerholm et al. (2012:428) have used a participatory mapping approach similar to ours. Quantifying the co-occurrence of pairs of services in rural Tanzania through correlation measures, they support this finding for some pairs of material and nonmaterial services as they find a strong link between livestock keeping, places identified as beautiful, and free time. Cocks et al.(2013) explored the emotional relationships of people with landscapes perhaps most explicitly. They showed that among Xhosa women and men of South Africa, activities such as collecting fuelwood, hunting, or spending time at initiation schools had the additional value of providing enjoyable time in nature. This value was associated with the experience of the forest itself, but also with the experience of the presence of ancestral spirits, offering protection and shaping cultural identity (Cocks et al. 2013). Interestingly, they found a gender difference, as women entered the forest in the context of more utilitarian purposes like work, whereas men, in addition to utilitarian purposes such as cattle herding or collecting medicinal plants, were found to spend time in the forest, often alone for days, as a spiritual sojourn or to encounter clan totem animals (Cocks et al. 2013:5).

There are striking parallels among the three recent studies. All report that material and nonmaterial services are intertwined in some places. Among them, Cocks et al. (2013) offer the most explicit explanations. Activities like hunting and collecting fuelwood provide material benefits and values as well as physical, spiritual, and mental well-being. The link is established through the worldview of the Xhosa people, who see the forest as the place where the ancestors come to communicate with their living descendants through animals. The description of the forest as shelter and protection can at least partly be attributed to these beliefs (Cocks et al. 2013:6).

Much in line with these findings, we have reported that many activities do not provide only food or pleasure, but both. However, the services may not only coexist, like spirits and fuelwood, in that they are found at the same place, but, as in Mahahe, they may become intertwined through activities like fishing, which supplies food, brings joy, and, for some, reinforces social relationships at the same time; much like the sociability Xhosa women enjoy when collecting fuelwood (Cocks et al. 2013).

Our ethnographic vignette describing the fishing trip shows that various services intertwine at the river. The material services include the food it provides while the fishermen spend the day there, as well as the fish they bring back to their homes. Another material service provided is the income generated if fish are sold. However, at the same time, during the activity the river, its surroundings and the fishing itself are experienced as beautiful. The people of Mahahe share a broad understanding of beauty, known as "uwa" in RuKwangali (Kloppers et al. 1994), which is not perceived solely in terms of the outward quality of an object but also as a general appreciation for a place that makes them feel good. Ontologically, beauty does not exist independently but can only be experienced through interacting with nature. In subsistence-oriented economies like Mahahe, these interactions are often embedded in the context of providing material ecosystem services including food and fuelwood. Hence, beauty cannot be understood as detached from activities, but exists through them. Although hardly anyone would go to the river merely to enjoy the cool breeze, such experiences are included as benefits of the activities of using provisional ecosystem services. However, fishing is not only material and beautiful. Both women and men fish in groups, and the situation allows gendered communication among peers and the exchange of stories and gossip, which are perceived as highly socially valuable. In addition, 
sharing time and food during the activities and the break inbetween creates belonging and forms group identities (Weissmantel 1995). Thus, this example offers an explanation of why and how material and nonmaterial services are linked in the culturally shared model: they are not separated in everyday practice.

Cultural consensus analysis allows us to empirically evaluate whether people's views of nature and the services it provides are idiosyncratic or culturally shared. Unlike among the Xhosa, where men and women differ in some valuations, in Mahahe, we found a very robust level of consensus in that informants largely agree on how they value nature. Having identified the cultural understanding, we can address the question of how this consensus can be explained. Ethnographic data suggest an answer. The livelihoods of the local population are relatively homogenous, which accounts for their rather similar uses and valuations of the landscape units. This is supported by the results of a socioeconomic baseline survey, collected in the larger area including Mahahe, within the larger Future Okavango project (Pröpper et al. 2013). The survey, conducted with 292 randomly selected households within Mahahe and the neighboring villages of Mupapama, Mashare, and Tjeye, shows that the majority of households $(87.3 \%)$ practice cropping activities for subsistence. Furthermore, $80.6 \%$ of all interviewed households engage in fishing and $92 \%$ collect fruits. $76.7 \%$ of local dwellings are constructed with wood and clay, and $72.1 \%$ have roofs thatched with grass, with only $26.2 \%$ covered with corrugated iron. The main water source for $62.5 \%$ of the respondents is the river, whereas $22.0 \%$ use public pipes. Livestock production makes up the largest part of the cash income available to informants, which is a total of $40.3 \%$ of household income. Thus, the survey data indicate relatively homogeneous resource utilization and livelihood strategies for a great number of the community households. In addition, the actors' practices regarding humanenvironmental interaction are, to a large extent, exercised in public with a high degree of visibility, and strategies are instantly communicated and exchanged within the village. Informants stated that they observe where neighbors obtain their resources, such as wild fruits and fuelwood, and adopt their sources in cases where they seem promising. Both processes contribute to a shared understanding of where valuable ecosystem services are located.

\section{CONCLUSION}

With the Millennium Ecosystem Assessment (2003), the ecosystem-service approach became a common framework for supporting natural resource management. However, the classification and concise valuation of ecosystem services is an ongoing challenge. Whereas "culture" has been used to name a subset of nonmaterial ecosystem services, it remains unclear what is really "cultural" about those services and what distinguishes them from the "natural" ones. From a methodological perspective, two solutions have been offered for empirically assessing cultural features, either by measuring a monetary value, or through qualitative assessments that are difficult to compare. Both uphold the nature/culture and material/nonmaterial divide. To overcome this divide, we have suggested an anthropological concept of culture as a social process of negotiating shared meanings and practices. We have argued that the valuation of cultural ecosystem services should not be restricted to the measurement of nonmaterial services provided by specific landscape units. Instead, shifting the focus from the analysis of culture as a residual category to the processes that underlie the valuation of nature in general, we define the cultural valuation of ecosystem services as the shared understanding of the landscape and the services it provides.

Our approach allows for the measurement of all ecosystem services on a single scale. This facilitates comparison and helps to overcome the common assumption that people's use of ecosystem services is either based on utilitarian and rational decisions, for natural services, or on arbitrary and nonrational decisions, for cultural services. As with monetary values, the cultural valuations found can be aggregated at the level of landscape units. They guide our understanding about which values are created and which are lost, from the local users' perspective, if natural resource management changes. Although we are not able to examine this in detail here, we have shown that different landscape units provide different numbers and compositions of services. For example, removing access to the river would not only cut off the supply of food, which could be substituted by more effective agriculture, but also other services, including the experience of beauty and social activities. Those services may not be easily substitutable for the individuals concerned (De Wet 2006). Therefore, the multidimensional meanings of nature should be integrated in conservation efforts, in impact assessments, and in scenarios aiming to produce a definition of environmental values (Cocks et al. 2013).

The approach introduced here does not provide an alternative to MA-inspired ecosystem assessments but rather offers a different perspective on them, one rooted in the perception and the understanding of people who interact with the environment. Whether those local valuations overlap or converge with (1) evaluations from other social groups, e.g., politicians and NGOs; and (2) scientific evaluations, remains an empirical question. Solving the possible discrepancies between them promises to be a compelling political, scientific, and epistemological challenge.

\section{Responses to this article can be read online at:} http://www.ecologyandsociety.org/issues/responses. php/6896

\section{Acknowledgments:}

The research upon which this article is based is funded by the German Federal Ministry of Education and Research (BMBF) and is part of The Future Okavango (TFO) project on anthropogenic influences and cultural dimensions of environmental uses in the Okavango catchment of Angola, Namibia, and Botswana. We are greatly indebted to the people of several communities within the project's research sites along the catchment. Felix Haupts, Björn Herold, Joao Baptista, Samwel T. Kwandu, and Lucas Kanumbo Mandjoro have shaped our understanding of the themes discussed as members of the research team. Moreover, we are obliged to Wolfgang Teichert for his assistance in creating the maps. Ted Lowe, Anastasia Weiß, Julia Pauli, and two anonymous reviewers provided very valuable comments on an earlier draft. 


\section{LITERATURE CITED}

Abu-Lughod, L. 1991. Writing against culture. Pages 137-162 in R.G. Fox, editor. Recapturing anthropology: working in the present. School of American Research Press, Santa Fe, New Mexico, USA.

Batchelder, W. H., and A. K. Romney. 1988. Test theory without an answer key. Psychometrika 53(1):7192. http://dx.doi. org/10.1007/BF02294195

Bateman, I. J., A. R. Harwood, G. M. Mace, R. T. Watson, D. J. Abson, B. Andrews, A. Binner, A. Crowe, B. H. Day, S. Dugdale, C. Fezzi, J. Foden, D. Hadley, R. Haines-Young, M. Hulme, A. Kontoleon, A. A. Lovett, P. Munday, U. Pascual, J. Paterson, G. Perino, A. Sen, G. Siriwardena, D. van Soest, and M. Termansen. 2013. Bringing ecosystem services into economic decisionmaking: land use in the United Kingdom. Science 341:45-50. http://dx.doi.org/10.1126/science.1234379

Brown, G. G., P. Reed, and C. C. Harris. 2002. Testing a placebased theory for environmental evaluation: an Alaska case study. Applied Geography 22:49-76. http://dx.doi.org/10.1016/S0143-6228 (01)00019-4

Brown, G. G., G. M. Montag, and K. Lyon. 2012. Public participation GIS: a method for identifying ecosystem services. Society and Natural Resources 25:633-651. http://dx.doi. org/10.1080/08941920.2011.621511

Chan, K. M. A., A. D. Guerry, P. Balvanera, S. Klain, T. Satterfield, X. Basurto, A. Bostrom, R. Chuenpagdee, R. Gould, B. S. Halpern, N. Hannahs, J. Levine, B. Norton, M. Ruckelshaus, R. Russell, J. Tam, and U. Woodside. 2012a. Where are cultural and social in ecosystem services? A framework for constructive engagement. BioScience 62:744-756. http://dx.doi.org/10.1525/ bio.2012.62.8.7

Chan, K. M. A., T. Satterfield, and J. Goldstein. $2012 b$. Rethinking ecosystem services to better address and navigate cultural values. Ecological Economics 74:8-18. http://dx.doi. org/10.1016/j.ecolecon.2011.11.011

Church, A., J. Burgess, N. Ravenscroft, W. Bird, K. Blackstock, E. Brady, M. Crang, R. Fish, P. Gruffudd, S. Mourato, J. Pretty, D. Tolia-Kelly, K. Turner, and M. Winter. 2011. Cultural services. Pages 633-691 in United Kingdom National Ecosystem Assessment, editor. The UK national ecosystem assessment technical report. United Nations Environment ProgrammeWorld Conservation Monitoring Centre (UNEP-WCMC, Cambridge, UK. [online] URL: http://uknea.unep-wcmc.org/

Cocks, M. L., and K. F. Wiersum. 2003. The significance of plant diversity to rural households in Eastern Cape province of South Africa. Forests, Trees and Livelihoods 13:39-58. http://dx.doi. org/10.1080/14728028.2003.9752443

Cocks, M. L. 2006. Bio-cultural diversity: moving beyond the realm of 'indigenous' and 'local' people. Human Ecology 34 (2):185-200. http://dx.doi.org/10.1007/s10745-006-9013-5

Cocks, M. L., T. Dod, and S. Vetter. 2013. 'God is my forest' Xhosa cultural values provide untapped opportunities for conservation. South African Journal of Science 108(5/6):8.
Costanza, R. 2008. Ecosystem services: multiple classification systems are needed. Biological Conservation 141:350-352. http:// dx.doi.org/10.1016/j.biocon.2007.12.020

Costanza, R., B. Fisher, S. Ali, and C. Beer. 2007. Quality of life: an approach integrating opportunities, human needs, and subjective well-being. Ecological Economics 61:267-276. http:// dx.doi.org/10.1016/j.ecolecon.2006.02.023

Costanza, R., I. Kubiszewski, D. Ervin, R. Bluffstone, J. Boyd, D. Brown, H. Chang, V. Dujon, E. Granek, S. Polasky, V. Shandas, and A. Yeakley. 2011. Valuing ecological systems and services. F1000 Biology Reports 3:14. [online] URL: http://f1000.com/ prime/reports/b/3/14 http://dx.doi.org/10.3410/B3-14

Costanza, R., R. d'Arge, R. de Groot, S. Farber, M. Grasso, B. Hannon, K. Limburg, S. Naeem, R. V. O’Neill, J. Paruelo, R. G. Raskin, P. Sutton, and M. van den Belt. 1997. The value of the world's ecosystem services and natural capital. Nature 387:253260. http://dx.doi.org/10.1038/387253a0

Costanza, R., M. Wilson, A. Troy, A. Voinov, S. Liu, and J. D'Agostino. 2006. The value of New Jersey's ecosystem services and natural capital. Gund Institute for Ecological Economics, University of Vermont, Burlington, Vermont, USA.

D'Andrade, R. 1995. The development of cognitive anthropology. Cambridge University Press, Cambridge, UK. http://dx.doi. org/10.1017/CBO9781139166645

Daily, G. C., S. Polasky, J. Goldstein, P. M. Kareiva, H. A. Mooney, L. Pejchar, T. H. Ricketts, J. Salzman, and R. Shallenberger. 2009. Ecosystem services in decision making: time to deliver. Frontiers in Ecology and the Environment 7:2128. http:// dx.doi.org/10.1890/080025

Daniel, T. C., A. Muhar, A. Arnberger, O. Aznar, J. W. Boyd, K. M. A. Chan, R. Costanza, T. Elmqvist, C. G. Flint, P. H. Gobster, A. Grêt-Regamey, R. Lave, S. Muhar, M. Penker, R. G. Ribe, T. Schauppenlehner, T. Sikor, I. Soloviy, M. Spierenburg, K. Taczanowska, J. Tam, and A. von der Dunk. 2012. Contributions of cultural services to the ecosystem services agenda. Proceedings of the National Academy of Sciences of the United Staes of America (PNAS) 109:8812-8819. http://dx.doi.org/10.1073/ pnas. 1114773109

De Groot, R. S., M. A. Wilson, and R. M. J. Bouman. 2002. A typology for the classification, description and valuation of ecosystem services, goods and services. Ecological Economics 41:393-408. http://dx.doi.org/10.1016/S0921-8009(02)00089-7

De Wet, C. 2006. Risk, complexity and local initiative in forced resettlement outcomes. Pages 180-202 in C. de Wet, editor. Development-induced displacement. Problems, policies and people. Berghahn, New York, New York, USA.

Denzin, N. 2005. Sociological methods: a sourcebook. Aldine Transaction, Chicago, Illinois, USA.

Descola, P. 2005. Par-delà nature et culture. Gallimard, Paris, France.

Fagerholm, N., N. Käyhkö, F. Ndumbaro, and M. Khamis. 2012. Community stakeholders' knowledge in landscape assessments: 
mapping indicators for landscape services. Ecological Indicators 18:421-433. http://dx.doi.org/10.1016/j.ecolind.2011.12.004

Fisher, B., and R. K. Turner. 2008. Ecosystem services: classification for valuation. Biological Conservation 141:11671169. http://dx.doi.org/10.1016/j.biocon.2008.02.019

Gadgil, M. 1987. Diversity: cultural and biological. Trends in Ecology and Evolution 2:369-373. http://dx.doi.org/10.1016/0169-5347 (87)90138-8

Geertz, C. 1973. The interpretation of cultures. Selcted essays. Basic, New York, New York, USA.

Groenfeldt, D. 2003. The future of indigenous values: cultural relativism in the face of economic development. Futures 35:917929. http://dx.doi.org/10.1016/S0016-3287(03)00049-1

Haines-Young, R., and M. Potschin. 2013. Common international classification of ecosystem services (CICES) consultation on version 4, August-December 2012. European Environment Agency, Copenhagen, Denmark. [online] URL: http://cices.eu/

Infield, M. 2001. Cultural values: a forgotten strategy for building community support for protected areas in Africa. Conservation Biology 15:800-802. http://dx.doi.org/10.1046/j.1523-1739.2001.015003800. $\underline{\mathrm{x}}$

Ingold, T. 2002 (1994). Introduction to culture. Pages 329-359 in T. Ingold, editor. Companion encyclopedia of anthopology. Taylor and Francis, London, UK.

Kloppers, J., D. Nakare, L. Isala, and A. Bredell. 1994. Bukenkango Rukwangali-English English-Rukwangali Dictionary. Gamsberg Macmillan, Windhoek, Namibia.

Kubiszewski, I., R. Costanza, L. Dorji, P. Thoennes, and K. Tshering. 2013. An initial estimate of the value of ecosystem services in Bhutan. Ecosystem Services 3:11-21. http://dx.doi. org/10.1016/j.ecoser.2012.11.004

Kumar, M., and P. Kumar. 2007. Valuation of the ecosystem services: a psycho-cultural perspective. Ecological Economics 64:808-819. http://dx.doi.org/10.1016/j.ecolecon.2007.05.008

Kuper, A. 1999. Culture: the anthropologists' account. Harvard University Press, Cambridge, Massachusetts, USA.

Laird, S. A. 1999. Forests, culture, and conservation. In D. A. Posey, editor. Cultural and spiritual values of biodiversity. $A$ complementary contribution to the global biodiversity assessment. United Nations Environment Programme, Nairobi, Kenya.

Latour, B. 1999. Pandora's hope: essays on the reality of science studies. Harvard University Press, Cambridge, Massachusetts, USA.

Lynam, T., W. de Jong, D. Sheil, T. Kusumanto, and K. Evans. 2007. A review of tools for incorporating community knowledge, preferences, and values into decision making in natural resources management. Ecology and Society 12(1): 5. [online] URL: http:// www.ecologyandsociety.org/vol12/iss1/art5/

Millenium Ecosystem Assessment (MA). 2003. Ecosystems and human well-being: a framework for assessment. World Resources Institute, Washington, D.C., USA.

Millenium Ecosystem Assessment. 2005. Ecosystems and human well-being: synthesis. Island, Washington, D.C., USA.
Maffi, L. 2005. Linguistic, cultural, and biological diversity. Annual Review of Anthropology 29:599-617. http://dx.doi. org/10.1146/annurev.anthro.34.081804.120437

Marcus, G. E., and M. M. J. Fischer. 1986. Anthropology as cultural critique: an experimental moment in the human sciences. University of Chicago Press, Chicago, Illinois, USA.

Medin, D., N. O. Ross, and D. Cox. 2006. Culture and resource conflict: why meanings matter. Russell Sage Foundation, New York, New York, USA.

Mendelsohn, J., and S. el Obeid. 2004. Okavango River. The flow of a lifeline. Struik, Cape Town, South Africa.

Moore, J. L., L. Manne, T. Brooks, N. D. Burgess, R. Davies, C. Rahbek, P. Williams, and A. Balmford. 2002. The distribution of cultural and biological diversity in Africa. Proceedings of the Royal Society of London. Biological Sciences (Series B) 269:1645-1653. http://dx.doi.org/10.1098/rspb.2002.2075

Murdock G. P. 1949. Social structure. Macmillan, New York, New York, USA.

Okeyo, D. O., G. Mubita, T. K. Harris, D. E. Sahombu, J. Namundjanga, S. Mulonga, and S. Kapirika. 2004. Indigenous names of fish and fishing gear in the Cuvelai, Kavango and Caprivi regions of Namibia. African Journal of Aquatic Science 29:249-258.

Plieninger, T., S. Dijks, E. Oteros-Rozas, and C. Bieling. 2013. Assessing, mapping, and quantifying cultural ecosystem services at community level. Land Use Policy 33:118-129. http://dx.doi. org/10.1016/j.landusepol.2012.12.013

Posey, D. A., editor. 1999. Cultural and spiritual values of biodiversity. United Nations Environment Programme, Nairobi, Kenya, and Intermediate Technology, London, UK.

Pröpper, M. 2009. Culture and biodiversity in central Kavango, Namibia. Reimer, Berlin, Germany.

Pröpper, M., T. Falk, S. Domptail, L. Große, and B. Kowalski. 2013. Partly subsistent household economies and modern consumerism in the Namibian Kavango: assets, income, expenditure and socio-economic stratification. Biodiversity and Ecology 5:379-391. http://dx.doi.org/10.7809/b-e.00290

Ramirez-Gomez, S. O. I., G. Brown, and A. Tjon Sie Fat. 2013. Participatory mapping with indigenous communities for conservation: challenges and lessons from Suriname. The Electronic Journal of Information Systems in Developing Countries 58(2):1-22.

Radcliffe-Brown, A. R. 1935. On the concept of function in social science. American Anthropologist 37(3):394-402. http://dx.doi. org/10.1525/aa.1935.37.3.02a00030

Raymond, C. M., B. A. Bryan, D. H. MacDonald, A. Cast, S. Sarah Strathearn, A. Agnes Grandgirard, and T. Kalivas. 2009. Mapping community values for natural capital and ecosystem services. Ecological Economics 68:1301-1315. http://dx.doi. org/10.1016/j.ecolecon.2008.12.006

Romney, A. K., S. C. Weller, and W. H. Batchelder. 1986. Culture as consensus: a theory of culture and informant accuracy. American Anthropologist 88:313-338. http://dx.doi.org/10.1525/ aa.1986.88.2.02a00020 
Romney A. K., W. H. Batchelder, and S. C. Weller. 1987. Recent applications of cultural consensus theory. American Behavioral Scientist 31:163-177. http://dx.doi.org/10.1177/000276487031002003

Satterfield, T., R. Gregory, S. Klain, M. Roberts, and K. M. Chan. 2013. Culture, intangibles and metrics in environmental management. Journal of Environmental Management 117:103114. http://dx.doi.org/10.1016/j.jenvman.2012.11.033

Satz, D., R. K. Gould, K. M. A. Chan, A. Guerry, B. Norton, T. Satterfield, B. S. Halpern, J. Levine, U. Woodside, N. Hannahs, X. Basurto, and S. Klain. 2013. The challenges of incorporating cultural ecosystem services into environmental assessment. Ambio 42:675-684. http://dx.doi.org/10.1007/s13280-013-0386-6

Shukdev, P. 2009. Costing the earth. Nature 462:277. http://dx. doi.org/10.1038/462277a

Silverman, B. W. 1986. Density estimation for statistics and data analysis. Chapman and Hall, London, UK. http://dx.doi. org/10.1002/bimj.4710300745

Skutnabb-Kangas, T., L. Maffi, and H. David. 2003. Sharing a world of difference: the earth's linguistic, cultural and biological diversity. UNESCO Publishing, Paris, France.

The Economics of Ecosystems and Biodiversity (TEEB). 2010. The economics of ecosystems and biodiversity: mainstreaming the economics of nature: a synthesis of the approach, conclusions and recommendations of TEEB. United Nations Environment Programme (UNEP), Geneva, Switzerland. [online] URL: http:// www.teebweb.org/wp-content/uploads/Study $\% 20$ and $\% 20$ Reports/ Reports/Synthesis $\% 20$ report/TEEB $\% 20$ Synthesis $\% 20$ Report $\% 202010$. pdf

Tylor, E. B. 1871. Primitive culture: researches into the development of mythology, philosophy, religion, language, art, and custom. J. Murray, London, UK. http://dx.doi.org/10.1037/13484-000

UK National Ecosystem Assessment (UKNEA). 2011. The UK national ecosystem assessment: synthesis of the key findings. UNEP-WCMC, Cambridge, UK.

Wallace, K. J. 2007. Classification of ecosystem services: problems and solutions. Biological Conservation 139:23-5246. http://dx. doi.org/10.1016/j.biocon.2007.07.015

Weismantel, M. 1995. Making kin: kinship theory and Zumbagua adoptions. American Ethnologist 22:685-704. http://dx.doi. org/10.1525/ae.1995.22.4.02a00010

Weller, S., R. Baer, J. de Alba Garcia, M. Glazer, R. Trotter, L. Pachter, and R. Klein. 2002. Regional variation in Latino descriptions of Susto. Culture, Medicine and Psychiatry 26:449472. http://dx.doi.org/http://dx.doi.org/10.1023/A:1021743405946

Weller, S. C. 2007. Cultural consensus theory: applications and frequently asked questions. Field Methods 19:339-368. http://dx. doi.org/10.1177/1525822X07303502

Werner, O., and H. R. Bernard. 1994. Ethnographic sampling. CAM-Cultural Anthropology Methods 1:7-9.

Wilson, M. A., and R. B. Howarth. 2002. Discourse-based valuation of ecosystem services: establishing fair outcomes through group deliberation. Ecological Economics 42:431-443. http://dx.doi.org/10.1016/S0921-8009(02)00092-7 